rights. Paris; 2006.

2. United Nations Educational, Scientific and Cultura Organization (UNESCO). Report of the International Bioethics Committee of UNESCO (IBC) on social responsibility and health. France: Social and Human Sciences Sector, Division of Ethics of Science; 2010.

3. Lundberg GD. The social responsibility of medical journal editing. J Gen Intern Med. 1987;2(6):415-9.

4. World Associations of Medical Editors (WAME). About us [Internet]. 2016 [cited 2020 Feb 28]. Available from: https:// wame.org/aboutus.
5. Moeloek NF. Indonesia national health policy in the transition of disease burden and health insurance coverage. Med J Indones. 2017;26(1):3-6.

6. The EQUATOR Network. Enhancing the quality and transparency of health research [Internet]. [cited 2020 Feb 28]. Available from: https://www.equator-network.org.

7. Menteri Kesehatan Republik Indonesia (Jakarta, Indonesia). Letter to Pimpinan Kementerian/Lembaga; Gubernur; Bupati/ Walikota Seluruh Indonesia (Indonesia). 2020 Mar 16. 4 leaf. Protokol isolasi diri sendiri dalam penanganan coronavirus disease (covid-19). No.:HK.02.01/MENKES/202/2020.

\title{
Visit to Singapore Medical Journal during COVID-19 outbreak: learning "beyond" the expectation
}

Felix Firyanto Widjaja, Windu Cahyaningrum Handayani Notonagoro Suryaningrat

In the end of January 2020, some members of the Editorial Team of Medical Journal of Indonesia (MJI) visited Singapore Medical Journal (SMJ). With the support from Prof. Wilfred CG Peh who is the Editorial Board Member of MJI and Past Editor-in-chief of SMJ, it is an honor to get approval from Prof. Poh Kian Keong as the current Editor-in-chief of SMJ for the visit. The SMJ has been published by the Singapore Medical Association since 1960, earlier than the MJI. The journal has also been indexed in well-known indexing databases, such as Index Medicus (PubMed) and Web of Science (Clarivate Analytics) with impact factor of 1.141 in $2018,{ }^{1}$ which means there was an average of 1.14 citations in 2018 from each published article during the period 2016-2017..$^{2}$ Moreover, the SMJ and the MJI share similar aim and scope in general medicine.
We learned much about journal management and manuscript handling from the four SMJ's editorial staff; and will adapt some adjustments for the MJI's improvements. Most of the journal in Indonesia was run as a "small medical journal", of which the editorial team needs to take part both as editor and publisher. As the editor, the editorial team has to guarantee the timely, accurate, and fair peer-review process; and ensure the availability of high-rate articles. In the meantime, as the publisher, the editorial team needs to ensure a user-friendly system for handling the manuscripts, ensuring high-quality print and electronic versions that are economically feasible, and finding potential revenue by advertising. ${ }^{3}$ The editorial team needs to overcome all the works while remaining committed to the publication ethics.

Figure 1. Total confirmed and tested cases of COVID-19 in Indonesia since March 1, 2020 (data from https:// infeksiemerging.kemkes. go.id)

*adjusted based on new criteria of suspected cases and contacts with confirmed case

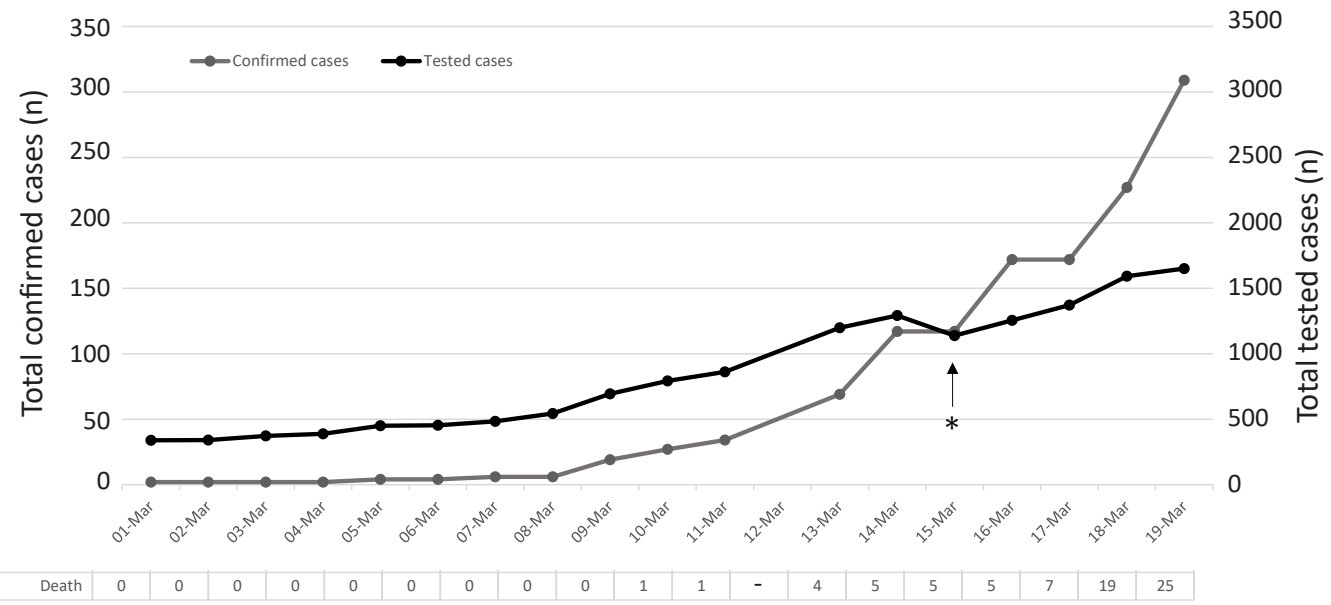

Copyright @ 2020 Authors. This is an open access article distributed under the terms of the Creative Commons Attribution-NonCommercial 4.0 International License (http:// creativecommons.org/licenses/by-nc/4.0/), which permits unrestricted non-commercial use, distribution, and reproduction in any medium, provided the original author and source are properly cited. For commercial use of this work, please see our terms at https://mji.ui.ac.id/journal/index.php/mji/copyright. 
Besides learning for the journal development, the visit taught us how they handle coronavirus disease-19 (COVID-19) outbreak and make us feel secure. The visit happened in January 31, 2020, a day after the World Health Organization (WHO) declared the disease as a public health emergency of international concern. ${ }^{4}$ At the time, 16 confirmed cases had been reported in Singapore. ${ }^{5}$ Before departure, some prevention efforts had been prepared from Indonesia. The WHO has advised the public to exert some protective efforts, e.g. washing hands regularly; maintaining social distance (at least 1 meter); avoiding touching face; implementing respiratory hygiene; and staying at home and seeking medical care as soon as fever, cough, and shortness of breath. ${ }^{6}$

The most important thing to fight panic is everybody needs to feel safe and secure that he/ she is in the protected environment and he/she will be taken care of when he/she gets the infection. Upon arrival at Changi Airport, we passed through thermal scanners to ensure no passengers with fever passing across Singapore to prevent the spread of COVID-19. This action also make people feeling safe. In the immigration area, the staff provided alcoholbased handrub to prevent the viral transmission. They also made on the advertisement that they doubled the cleaning services in the airport to keep people secure. At the SMJ office building, the staff provided a checkpoint to screen temperature using an infrared thermometer. Moreover, all visitors were asked to accomplish a questionnaire on which they asked information about symptoms, date, telephone number, and email address to facilitate the tracing process in case of potential infection. It is once again an effort to make people being in a safe environment.

To make us secure, we also made some precautions by preparing masks and alcohol-based handrubs from Indonesia. Although, the WHO has advised that the mask be worn only by persons who are coughing and sneezing or by healthy people who are taking care of a suspected case. Before using a mask, the hand should be cleaned. The mask has to cover the mouth and nose, and the wearer should avoid touching the front of the mask. After using the mask, it should be removed from behind without touching the front and thrown away in a garbage bin. The user should clean the hands immediately. ${ }^{7}$ Moreover, to keep us in good conditions, the schedule had been arranged comfortably. All the team needed to eat regularly and had vitamin supplementation. It was continued at the office after the visit during the next two weeks by limiting the work-hour and having supplementation.

On March 1, 2020, Indonesia had first two confirmed cases of COVID-19. ${ }^{8}$ (Figure 1) The case fatality rate of COVID-19 reached 4.1\% worldwide (data on March 19, 2020). ${ }^{8}$ Specifically, the Chinese data showed that $81 \%$ of the COVID-19 death case were aged $\geq 60$ years old and the case fatality rate of COVID-19 in patients of age $<60$ years old was only $0.63 \% .^{9}$

There is currently no vaccine and definite treatment available for this disease. Scientists have started to develop diagnostic tools, potential treatments, and also vaccines. As of March 15, 2020, a total of 94 clinical studies with the keyword "COVID-19" had been found in ClinicalTrials.gov. Three studies on the vaccine (mRNA-173 COVID-19 artificial antigen presenting cell vaccine, and lentiviral minigene vaccine) have been started for safety and immunogenicity. ${ }^{10}$ A study for antiviral treatment of COVID-19 showed lopinavir/ritonavir was not more superior than standard care in hastening the number of days of clinical improvement, reducing mortality risk, and minimizing the adverse event. ${ }^{11}$ Other clinical studies are trying to find antiviral and supportive treatment for COVID-19, e.g. ribavirin, remdesivir, darunavir and cobicistat, ASCogF+oseltamivir, ritonavir+oseltamivir, hydroxychloroquine, choloroquine, interferon beta-1b, natural killer cells treatment, bevacizumab, meplazumab as antiCD147, Arbidol, Abidol hydrochloride, anti PD-1, T89 drug, methylprednisolone, recombinant human angiotensin-converting enzyme 2, thalidomide, carrymycin, umbilical cord-derived mesenchymal stem cells, immunoglobulin of cured patients, washed microbiota transplantation, and so on. ${ }^{10}$ We expect to hear good news about these new developments to solve this crisis.

Other concern to avoid fear and panic is the government need to assure that all stakeholders put their best to control the disease and are responsible to inform the action and share valid information. It is essential for everybody to read and share verified information in any kind of media. ${ }^{12}$ As an editor, we also need to make sure that we spread valid and reliable information by ensuring peer review process. In the meantime, avoiding panic and prevention is the best way to control this pandemic. 
From Medical Journal of Indonesia pISSN: 0853-1773 • elSSN: 2252-8083

https://doi.org/10.13181/mji.ed.204615

Med J Indones. 2020;29:3-5

Corresponding author:

Felix Firyanto Widjaja

E-mail: felixfw@gmail.com

\section{REFERENCES}

1. Singapore Medical Journal. About SMJ [Internet]. 2019 [cited 2020 Feb 27]. Available from: http://www.smj.org.sg/about-smj.

2. Nestor MS, Fischer D, Arnold D, Berman B, Del Rosso JQ. Rethinking the journal impact factor and publishing in the digital age. J Clin Aesthet Dermatol. 2020;13(1):12-7.

3. Alpert JS, Tagler J. The publisher and the editor: friend and foe. Am J Med. 2014;127(12):1137-8.

4. World Health Organization. A joint statement on tourism and COVID-19 - UNWTO and WHO call for responsibility and coordination [Internet]. 2020 [cited 2020 Feb 27]. Available from: https://www.who.int/news-room/detail/27-02-2020-ajoint-statement-on-tourism-and-covid-19---unwto-and-who-callfor-responsibility-and-coordination.

5. Ministry of Health Singapore. Official update of COVID-19 situation in Singapore [Internet]. 2020 [cited 2020 Feb 27]. Available from: https://experience.arcgis.com/experience/7ezo edc490a5441a874fgefe67bd8b89.

6. World Health Organization. Coronavirus disease (COVID-19) advice for the public: basic protective measures against the new coronavirus [Internet]. 2020 [cited 2020 Feb 27]. Available from: https://www.who.int/emergencies/diseases/novelcoronavirus2019/advice-for-public.

7. World Health Organization. Coronavirus disease (COVID-19) advice for the public: when and how to use masks [Internet] 2020 [cited 2020 Feb 27]. Available from: https://www.who. int/emergencies/diseases/novel-coronavirus-2019/advice-forpublic/when-and-how-to-use-masks.

8. Ministry of Health of the Republic of Indonesia. Corona virus update [Internet]. 2020 [cited 2020 Mar 19]. Available from: https://infeksiemerging.kemkes.go.id/.

9. Novel Coronavirus Pneumonia Emergency Response Epidemiology Team. Chinese Center for Disease Control and Prevention. [The epidemiological characteristics of an outbreak of 2019 novel coronavirus diseases (COVID-19) in China]. Zhonghua Liu Xing Bing Xue Za Zhi. 2020;41(2):145-51. [Chinese].

10. National Institutes of Health. 94 studies found for: COVID-19 [Internet]. 2020 [cited 2020 Mar 15]. Available from: https:// clinicaltrials.gov/ct2/results?cond=COVID-19\&term $=\&$ cntry $=\&$ st ate $=\&$ city $=\&$ dist $=$.

11. Cao B, Wang Y, Wen D, Liu W, Wang J, Fan G, et al. A trial of lopinavir-ritonavir in adults hospitalized with severe covid-19. N Engl J Med. 2020.

12. Lancet. COVID-19: fighting panic with information. Lancet. 2020;395:537. 